\title{
Protein Digestion-Derived Peptides and the Peripheral Regulation of Food Intake
}

\author{
Juliette Caron ${ }^{\dagger}$, Dorothée Domenger ${ }^{\dagger}$, Pascal Dhulster, Rozenn Ravallec and \\ Benoit Cudennec*
}

Université Lille, INRA, Université Artois, Université Littoral Côte d'Opale, EA 7394 - ICV - Institut Charles Viollette, Lille, France

\section{OPEN ACCESS}

Edited by:

Hubert Vaudry,

University of Rouen, France

Reviewed by:

Hiroshi Hara,

Hokkaido University, Japan

Leo T. O. Lee,

University of Macau, China

*Correspondence:

Benoit Cudennec benoit.cudennec@univ-lille1.fr

tThese authors have contributed equally to this work.

Specialty section: This article was submitted to Neuroendocrine Science, a section of the journal Frontiers in Endocrinology

Received: 25 January 2017 Accepted: 03 April 2017

Published: 24 April 2017

Citation:

Caron J, Domenger D, Dhulster P, Ravallec R and Cudennec B (2017) Protein Digestion-Derived Peptides and the Peripheral Regulation of Food Intake.

Front. Endocrinol. 8:85. doi: 10.3389/fendo.2017.00085
The gut plays a central role in energy homeostasis. Food intake regulation strongly relies on the gut-brain axis, and numerous studies have pointed out the significant role played by gut hormones released from enteroendocrine cells. It is well known that digestive products of dietary protein possess a high satiating effect compared to carbohydrates and fat. Nevertheless, the processes occurring in the gut during protein digestion involved in the short-term regulation of food intake are still not totally unraveled. This review provides a concise overview of the current data concerning the implication of food-derived peptides in the peripheral regulation of food intake with a focus on the gut hormones cholecystokinin and glucagon-like peptide 1 regulation and the relationship with some aspects of glucose homeostasis.

Keywords: protein digestion, bioactive peptides, food intake regulation, gut hormones, dipeptidyl peptidase IV, enteroendocrine cells

\section{INTRODUCTION}

Food intake regulation strongly relies on the gut-brain axis, and numerous studies have pointed out the significant role played by gut hormones in response to food digestion $(1,2)$. These hormones are involved in appetite regulation as short-term peripheral satiety signals. They promote satiety, i.e., diminish appetite and reduce food intake by endocrine and nervous paths activating different signaling pathways (3-5).

The increasing expansion of obesity-related diseases has led the scientific community to explore new therapeutic approaches. They need to promote long-term body weight decrease and stabilization, especially fat loss, as well as satiety while reducing caloric intake (6). Dietary proteins have a greater satiety effect than carbohydrates and fat when equally consumed (7). However, this effect may rely on the protein source (8). Satiating properties of dietary proteins come from various physiological effects such as gut hormone secretion stimulation, energy expenditure and amino acid circulating level increase, and gluconeogenesis stimulation (9). Nevertheless, the mechanisms occurring in the gut and leading to the release of peripheral signals (e.g., gut hormones) implicated in the short-term regulation of food intake are still unclear. In the context of obesity and type 2 diabetes mellitus (T2DM) management, protein intake has revealed interesting positive effects on glycemia decrease, insulin secretion, and body fat loss (10). So far, the beneficial effects of protein intake on energy homeostasis remain partially elucidated but have been mainly attributed to amino acid composition (6). Bioactive peptides have emerged as potential molecules accounting for the positive effects of protein intake on weight loss and glycemia management. The process of gastrointestinal (GI) digestion is able to release bioactive peptides at circulating levels that might exert significant physiological 
effects on energy homeostasis. Unfortunately, their quantification in vivo still remains challenging. Some food protein-derived peptides, especially from dairy proteins, have demonstrated several biological activities, and these have been well characterized in relation to glycemia management (11). Nevertheless, the many bioactivities of food-derived peptides described so far still need to be better defined and integrated in a context of physiological function. Here, we review the involvement of protein-derived bioactive peptides in the short-term regulation of food intake and the mechanisms of protein-induced satiety, with a special focus on the gut hormones, cholecystokinin (CCK), and glucagon-like peptide 1 (GLP-1) on the one hand, and some aspects of glucose homeostasis on the other hand.

\section{CCK SECRETION AND BIOACTIVE PEPTIDES}

Cholecystokinin, mainly secreted by enteroendocrine I cells located in the upper intestinal tract, acts at different levels on food intake regulation. It retards gastric emptying, stimulates pancreatic secretion and decreases food intake. Several studies in rats or humans have proved that protein or protein hydrolyzate intake could stimulate CCK secretion correlated with a gastric emptying decrease $(12,13)$, inhibit intraluminal protease activity (14) or decrease food intake (15). The GI digestion process appears as a key step which emphasizes the satiating properties of dietary proteins. Several in vivo and in vitro studies with intact proteins, their hydrolyzates or corresponding amino acid mixtures illustrate this phenomenon. Indeed, peptides are sequentially released throughout GI digestion and are, with fatty acids, the main stimuli of CCK release. Sharara et al. have shown that a protein intake stimulated postprandial secretion of CCK in rats, though indirectly, whereas free amino acid intake had no effect (16). Soy protein or casein intake in rats caused a delay in food intake decrease compared to the one induced by the respective protein hydrolyzates. This might be due to a slower release of peptides occurring during intact protein GI digestion (17). In vitro, the STC-1 murine enteroendocrine cell (EEC) line is widely used for intestinal hormones synthesis and secretion studies. Using this model, the greater CCK stimulating potential of various peptones or protein hydrolyzates than the equivalent mixtures of free amino acids has been shown and further investigated. Amino acid mixtures representing the composition of various protein hydrolyzates such as soy protein (18), blue whiting or shrimp $(19,20)$ or various animal peptones $(21)$ displayed lower CCK enhancing effects than their associated hydrolyzates. A beneficial effect of a longer pepsin hydrolysis time has been observed on the CCK enhancing potential of a soy protein hydrolyzate (18). The peptide structure thus seems a key determinant in the stimulation of CCK secretion, although this is still questionable (22). This brings light to the central role played by the GI digestion process in generating bioactive peptides from ingested dietary proteins. Proteins preloads studies have proved to decrease food intake during meals and to faster induce satiety. Interestingly, a preload of whey proteins administrated to healthy subjects significantly decreased food intake and stimulated satiety compared to a preload of caseins, and this has been partially linked to a higher plasmatic CCK level (8). Thus, the type of protein source seems to influence the CCK enhancing potential, but this still needs to be clearly demonstrated.

Once released into the lumen, peptides come in contact with the brush border barrier where they can stimulate gut hormone secretion. All the known different pathways have been summarized in Figure 1.

Nishi et al. have isolated a peptide fragment of soy $\beta$-conglycinin ( $\beta$ 51-63) able to induce food intake decrease in rats correlated to enhanced CCK levels. This fragment showed in vivo to have the strongest ligand affinity for a rat intestinal membrane (estimated by surface plasmon resonance) compared to other $\beta$-conglycinin fragments whose CCK enhancing potentials were lower (23). The high occurrence of arginine residues in this particular bioactive fragment could partially account for the CCK enhancing effects (13). Concomitantly, a pork hydrolyzate showed a very high ligand affinity with rat brush border membrane correlated to a dose-dependent CCK enhancing effect on the murine STC-1 cell line. Moreover, an orogastric preload of this pork hydrolyzate significantly reduced food intake in rats (24). Dietary peptides could directly stimulate CCK secretion in I cells, or indirectly in the mucosa involving intermediate factors such as luminal CCK-releasing factor (LCRF) (25). Originally purified as a 70-75 amino-acid residue peptide from rat jejunum secretion (26), LCRF was found at the highest levels in the small intestine but is present in different parts throughout the GI tract (27). LCRF was identified after several studies showing that CCK release and pancreatic secretions were inhibited by trypsin, chymotrypsin, and elastases implying an intraluminal factor, sensitive to proteases, that elicits CCK secretion (28). Early studies tested the bioactivity of different LCRF fragments and highlighted the activity of fragment 11-25 but not 1-6 for instance, in accordance with the susceptibility of LCRF bioactivity to intestinal and pancreatic enzymes degradation (29). Further, it has been shown that LCRF acts directly on CCK-secreting cells also via an increase in intracellular calcium at least involving the L-type calcium channel (25). The intestinal mucosa possesses a wide variety of cells in addition to the EECs, which might be stimulated by peptides and be involved in CCK secretion. Receptors and signaling pathways involved have only been partially characterized so far. Intracellular calcium mobilization has been first pointed out using in vitro cell lines. Némoz-Gaillard et al. have demonstrated that egg white albumin peptones stimulated CCK secretion via a toxin pertussis sensitive $\mathrm{G}$ protein inducing a $\mathrm{Ca}^{2+}$ cytosolic input through voltage-dependent $\mathrm{Ca}^{2+}$ channels in STC-1 cells (30). Activation of $\mathrm{Ca}^{2+}$ channels can be the first step of the signaling pathway leading to CCK secretion: L-type channels are activated by diazepam-binding inhibitor (DBI), which has been isolated from rat intestinal mucosa, inducing CCK secretion (31). GPR93, also known as GPR92, is part of the G protein-coupled receptors (GPCR) investigated for their possible link between nutrient sensing and the transduction to GI cell functions. It is highly expressed in the intestine and has been found to respond to a protein hydrolyzate in rat enterocytes and non-tumorigenous rat enterocytes cell line (hBRIE380) (32). GPR93 is also endogenously expressed by STC-1 cells where its overexpression and 


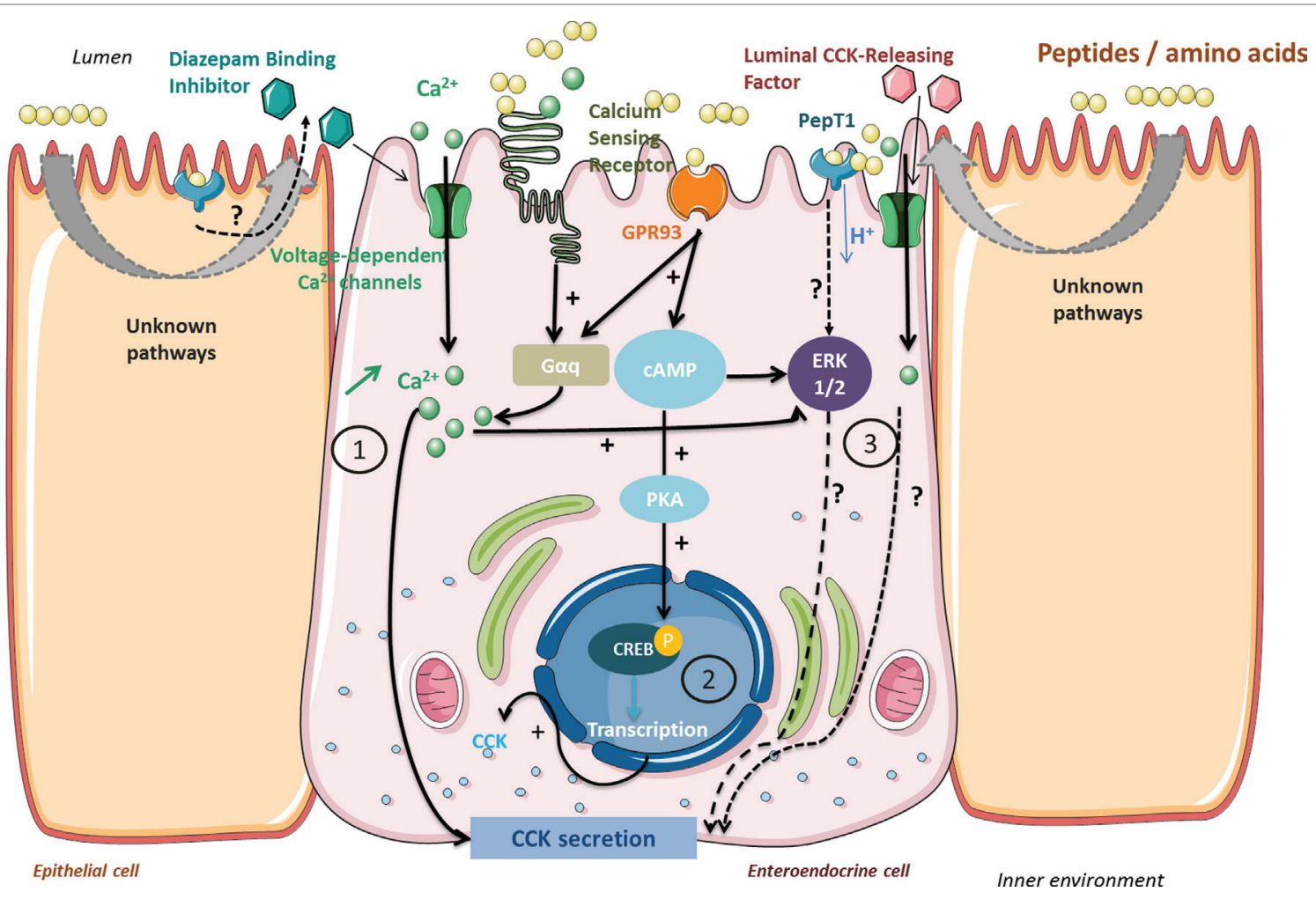

FIGURE 1 | Signaling pathways activated by peptides and amino acids involved in cholecystokinin (CCK) secretion and synthesis in enteroendocrine cells. Peptides from protein gastrointestinal digestion released in the lumen stimulate CCK secretion via (1) calcium-sensing receptor (CaSR) or GPR93 activation causing an intracellular $\mathrm{Ca}^{2+}$ increase. Voltage-dependent $\mathrm{Ca}^{2+}$ channels enable an extracellular $\mathrm{Ca}^{2+}$ uptake when activated by CaSR and GPR93 or by membrane depolarization following dipeptide transport by PepT1. GPR93 activation by peptides may initiate CCK gene transcription (2) by ERK 1/2 or phosphokinase A signaling pathway activation. Other pathways are still investigated (3) and might indirectly imply PepT1 or luminal CCK-releasing factor in CCK secretion.

activation by peptones lead to increases in CCK transcription and release (33). Further investigation of the transduction pathway revealed the involvement of $G_{\alpha}$ proteins, a dose-dependent intracellular $\mathrm{Ca}^{2+}$ increase and the ERK 1/2. The calcium-sensing receptor (CaSR) is the other receptor involved in luminal peptide detection linked to CCK secretion stimulation. Part of the C family of GPCR, CaSR possesses an N-terminal Venus fly trap (VFT) domain located in the extracellular side rich in cysteine residues (34). CaSR is activated by various metabolites, extracellular $\mathrm{Ca}^{2+}$, and basic L-amino acids for which the VFT domain is required. CaSR is expressed in numerous tissues including the GI tract and is involved in calcium metabolism (35). CaSR is implicated in the stimulation of CCK secretion in the presence of $\mathrm{L}$-phenylalanine, a well-known CCK secretion stimulator, in STC-1 cells (36). CaSR phenylalanine activation induces an intracellular $\mathrm{Ca}^{2+}$ mobilization ending up with CCK secretion (37). Peptide $\beta$ 51-63 from $\beta$-conglycinin, a CCK-enhancing stimulator in STC- 1 cells, provokes an intracellular $\mathrm{Ca}^{2+}$ increase mediated by CaSR (38). The authors later demonstrated that CaSR was also involved in protein hydrolyzate detection and CCK secretion stimulation. Treating cells with a specific CaSR antagonist significantly affected the CCK response in the presence of protein hydrolyzates (39). Even though protein hydrolyzates contain a significant part of free amino acids, low molecular weight peptides $(>1,000 \mathrm{Da})$ have been suggested to be the best stimuli of CCK secretion via CaSR activation. However, to the best of our knowledge, no peptide sequence has been characterized as CaSR specific.

Dietary peptides influence CCK secretion stimulation at different levels, but they also turn out to be influencing CCK gene transcription. Thus, Cordier-Bussat et al. showed that meat and egg albumin peptones had a dose-dependent effect on CCK secretion stimulation in STC-1 cells but also on the mRNA levels of the CCK gene (21). The authors later proved that peptones were able to stimulate cAMP release and to promote phosphokinase A (PKA) activation that induces CREB transcription factor phosphorylation, activating the CCK gene promoter in STC-1 cells (40). Choi et al. also noticed in STC-1 cells that GPR93 activation by peptones, or a specific agonist, led to an increase in CCK mRNA levels. Peptones were able to activate the PKA pathway that promoted the activation of the CCK gene promoter, and this has not been stated with the specific agonist. GPR93 activation by oligopeptides activates several signaling pathways that might influence both CCK synthesis and secretion (33). Indeed, Choi et al. studies in the STC-1 model implicated the ERK1/2 (MEK), PKA, and calcium/calmodulin-dependent protein kinase (CaMK) pathways in the mediation of CCK upregulation. Furthermore, Gevrey et al. work, also in STC-1 cells, had already shown peptone-induced involvement of the cAMP, PKA, and 
CREB as the primary pathway, together with a $\mathrm{Ca}^{2+}$ dependent ERK1/2 (MEK) pathway and a minor involvement of CaMK on CCK gene promoter activity. They demonstrated a total inhibition of this promoter activity when all pathways were blocked, suggesting crosstalk between them. Previous evidence of possible interactions between the cAMP and ERK pathways in different cell types also exists (41-43).

Anorexigenic effects of dietary peptides are also mediated by peripheral CCK-1R $(13,17,44)$. Raybould et al. have proved that luminal nutrients stimulated CCK secretion that activates vagal afferents and inhibits gastric emptying (45). Later, Darcel et al. have pointed out that the di/tripeptides transporter PepT1 was also implied in the CCK secretion signaling pathway. The authors demonstrated that a duodenal infusion of meat peptones led to a vagal afferent discharge inhibited by a PepT1 inhibitor infused in the duodenal mucosa (46). The indirect role of PepT1 in CCK secretion induced by protein hydrolyzates was clearly pointed out in STC-1 cells as well as in native human intestinal I cells. Indeed, these cells were activated by PepT1 agonists, but this effect was not associated with CCK secretion alteration and was not affected by PepT1 antagonist treatment (47). These authors thus excluded a direct role of PepT1 in mediating the effect of peptone on CCK secretion. To account for an indirect role of PepT1, it was suggested that this transporter on enterocytes could promote a signaling factor release like the DBI that would trigger CCK release by I-cells. Moreover, although these authors found PepT1 transcripts in these cells, STC-1 expression of PepT1 could not be confirmed by another group (48). Remarkably, dietary peptides can also behave as CCK-1R agonists: soy or potato protein hydrolyzates known as CCK secretion stimuli in STC-1 cells, additionally act as partial agonists of CCK-1R in CCK-1R-overexpressing $\mathrm{CHO}$ cells. In the case of soy protein hydrolyzate, Staljanssens et al. demonstrated that the $\beta$-conglycinin hydrolyzates generated by GI digestion partially activate CCK-1R in CHO-CCK-1R cells but also probably other receptors involving an intracellular calcium response. Indeed, elevation of intracellular calcium was also noted in the native $\mathrm{CHO}$ cells, and more puzzling, this effect was decreased in the presence of a CCK-1R antagonist in both cell types (49). As the intestinal mucosa is densely innervated, vagal afferents expressing CCK-1R could be accessible to luminal content and be directly activated by dietary peptides (50). Lately, a study in vagotomized pigs has questioned the predominant role of the vagus nerve. CCK-1R blockade in abdominal vagal afferents did not abolish plasmatic CCK level increase and satiety after a liquid meal (51). This highlights that other peripheral CCK-1R could be involved and might have a greater role than the ones located in vagal afferent neurons.

To summarize, dietary peptides activate distinct signaling pathways involved in CCK secretion that promotes satiety and decrease food intake. They act in EECs by activating specific receptors (GPR93, CaSR) that, in response, induce CCK secretion stimulation via intracellular calcium mobilization. Peptides may indirectly act on the intestinal mucosa and stimulate the secretion of intermediate factors (LCRF) inducing CCK secretion in EECs. Another pathway stimulated by dietary peptides might involve PepT1 but has not been fully characterized yet. Peptides may also interact with CCK-1R either as partial agonist in vagal afferents located in the intestinal mucosa or indirectly by activating a PepT1 involving signaling pathway. Finally, peptides regulate CCK synthesis at the CCK gene transcription level, but the pathways involved have to be further elucidated.

\section{GLP-1 SECRETION AND BIOACTIVE PEPTIDES}

Glucagon-like peptide 1 plays a significant role in energy homeostasis: it regulates blood glucose via its incretin action and promotes satiety and food intake decrease via its anorexigenic properties. That is why GLP-1 has recently emerged as an interesting therapeutic target in T2DM and obesity treatment approaches. Positive results from bariatric surgery on T2DM and obese subjects (sustainable weight loss, blood glucose regulation improvement) were partially attributed to elevated plasmatic GLP-1 levels, but these still remain partially unresolved (52). Dietary protein intake is one of the stimuli of GLP-1 secretion in EECs of the L-type, more abundant in the distal intestine, and activates several signaling pathways (Figure 2). GLP-1 effects were described after dietary protein intake from either animal sources, especially milk-derived proteins (53) or plant sources (54). A whey protein load before a meal led to a faster food intake decrease and satiety stimulation correlated to higher circulating GLP-1 levels in healthy subjects (55). A high-protein diet significantly increased postprandial GLP-1 levels compared to a conventional protein diet in healthy subjects, and extended satiety was partially attributed to these elevated GLP-1 levels (56). A preload of blue whiting administered to rats induced a short-term food intake decrease correlated to a plasmatic CCK and GLP-1 level increase (20). Beyond their satiating properties, dietary proteins can also improve blood glucose via GLP-1 secretion stimulation and plasmatic dipeptidyl peptidase IV (DPP-IV) activity inhibition (57-60). Whey proteins are a well-known source of bioactive peptides stimulating GLP-1 secretion, inhibiting plasma DPP-IV activity, and stimulating insulin secretion in pancreatic cells (61). However, the GLP-1-enhancing potential of proteins was found weaker than other macronutrients since lipid- or carbohydratebased meals led to higher GLP-1 levels than after a high-protein diet (62). Moreover, an increase of the plasma GLP-1 level is not always associated with satiating effects (63). The reproducibility of GLP-1 satiating effects seems to strongly rely on several parameters such as the physiological state of the patient or experimental conditions of the study like the presence of other macronutrients, the protein source, and the delay duration after preload administration. This tends to make the comparison between different studies delicate (64). Regarding the secretion trigger mechanisms of GLP-1, two ways have been uncovered that explain the biphasic secretion of GLP-1. First, the activation of vagal afferents located in the duodenum, which indirectly stimulates GLP-1 secretion in distal EECs, then a direct contact with the EECs located in the ileum $(65,66)$. In vitro cell models have been widely developed to better understand the mechanisms of nutrient chemosensing. Animal (meat, egg white albumin) or plant protein (zein, rice) hydrolyzates have demonstrated GLP-1 enhancing properties in murine EEC lines such as STC-1 (67) and GLUTag $(60,66)$ or 


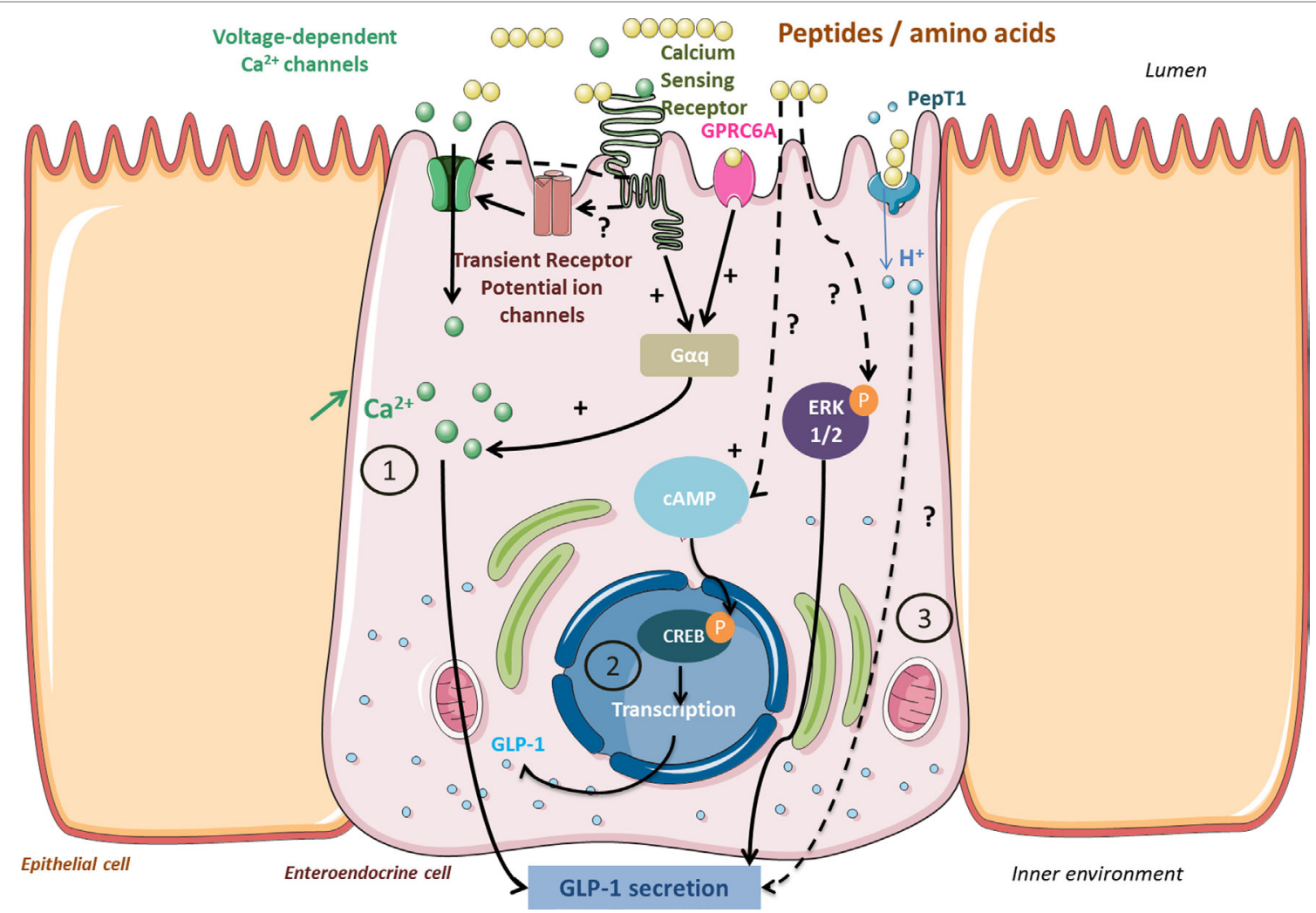

FIGURE 2 | Signaling pathways activated by peptides and amino acids involved in glucagon-like peptide 1 (GLP-1) secretion and synthesis in enteroendocrine cells. Peptides from protein gastrointestinal digestion released in the lumen stimulate GLP-1 secretion via calcium-sensing receptor (CaSR) or GPRC6A activation (1). In return, they activate a Goq subunit that activates PLC- and IP3-dependent signaling pathways and provokes an intracellular Ca2+ increase. Activation of $\mathrm{Ca}^{2+}$ channels by CaSR or transient receptor potential channels enables $\mathrm{Ca}^{2+}$ uptake. Peptides may also activate proglucagon gene transcription via a cAMP-dependant pathway leading to CREB phosphorylation (2). Unknown pathways involved in GLP-1 secretion might involve ERK 1/2 phosphorylation or proton uptake coupled to peptide transport in PepT1 (3).

human cell lines such as NCI-H716 (68). Free amino acids also have GLP-1 enhancing properties, but the resulting effect appears lower than for peptides $(20,67)$. Mechanisms of GLP-1 secretion triggered by free amino acids have been deeper investigated. L-Glutamine induces membrane depolarization and activation of a metabolic pathway involving intracellular calcium mobilization in GLUTag cells (69). This pathway has later been confirmed in primary intestinal cells where L-glutamine-induced membrane depolarization was associated to cAMP and intracellular calcium increases, probably mediated by a GPCR (70). However, in both healthy and T2DM patients, encapsulated L-glutamine ingestion did not influence GLP-1 levels to significantly induce beneficial metabolic effects. Surprisingly, L-glutamine intake was even followed by food intake increase and suggested that L-glutamine might interact with orexigenic pathways (71). CaSR, preferentially activated by aromatic amino acids and expressed in EECs, is one of the receptors involved in the GLP-1 secretion pathway. Indeed, amino acids such as phenylalanine, tryptophan, glutamine, or asparagine have shown a GLP-1 enhancing effect in isolated rat intestines, and this was strongly altered by a specific CaSR antagonist (72). Another GPCR, of the class C, named GPRC6A has been characterized as an amino acid chemodetector more sensitive to basic amino acids exhibiting hydroxyl or sulfuryl groups. Extracellular binding of L-ornithine with GPRC6A triggered GLP-1 exocytosis by activating the intracellular calcium and inositol triphosphate related pathway in GLUTag cells (73).

Activation pathways triggered by peptides are under investigation but display certain similarities with those activated by amino acids such as intracellular calcium increase. One tetrapeptide of glycine residues stimulates GLP-1 secretion in NCI-H716 cells associated to intracellular calcium increase (74). Two distinct peptide sensing pathways have been highlighted in native L cells, one involving CaSR activation and intracellular calcium variation and the other peptide transport by PepT1 associated with membrane depolarization (75). Other transporters are involved in calcium regulation, such as voltage-dependent $Q$ type channels or transient receptor potential channels and might be activated by protein hydrolyzates. Thus, they might participate in the GLP-1 secretion as suggested in a study realized in murine native EECs (76). Another intracellular signaling pathway has been characterized in NCI-H716 cells and involves MAP kinase metabolites: ERK1/2 phosphorylation activated by meat peptones triggers GLP-1 secretion (77). Finally, dietary peptides in the form of protein hydrolyzates are also able to positively influence proglucagon 
gene transcription in both STC-1 and GLUTag cells $(67,78)$ by cAMP increase and CREB transcription factor phosphorylation (79). To the best of our knowledge, the tetra-glycine peptide was the only peptide sequence known for its GLP-1enhancing properties until recently; our group identified three peptides, obtained from the GI digestion of bovine hemoglobin, able to highly stimulate GLP-1 secretion in STC-1 cells: ANVST, TKAVEH, and KAAVT (80).

\section{BIOACTIVE PEPTIDES AND DPP-IV ACTIVITY: GLP-1 ACTIVITY REGULATION AND INDIRECT EFFECT ON GLUCOSE HOMEOSTASIS}

Dipeptidyl peptidase IV is a serine exopeptidase that removes dipeptides from the $\mathrm{N}$-terminal side of substrates, including GLP-1 and GIP, by cleaving post-proline or -alanine residues (81). It cleaves and de facto quickly inactivates GLP-1 following its secretion and therefore appears as a strong inhibitor of its activities (82). DPP-IV exists in transmembrane and soluble active forms and is expressed in various tissues and fluids. It has also been implicated in many other regulatory processes by its interaction with neuropeptides or chemokines (83). Today, DPP-IV inhibitors are thus considered an advanced class of agents for T2DM management due to their effects on the GLP-1 availability and recovery of the incretin effect. In this way, the oral administration of DPP-IV inhibitors (gliptins) is the most recent alternative treatment of T2DM (84). However, numerous works have pointed out the advantage to identify "natural" as in foodderived peptide inhibitors of DPP-IV activity as an alternative for synthetic inhibitors to reinstate the incretin effect in T2DM. GI dietary protein digestion is a natural enzymatic hydrolysis release of bioactive peptides that could exhibit DPP-IV inhibitory potentials close to those of peptides released under controlled enzymatic hydrolysis. $\mathrm{IC}_{50}$ values of various digests generally range from 1 to $5 \mathrm{mg} \cdot \mathrm{mL}^{-1}$ like numerous protein hydrolyzates. As an example, several milk protein digests, generated under in vitro conditions, reached similar $\mathrm{IC}_{50}$ values compared to protein hydrolyzates obtained with microbial enzymes such as Alcalase ${ }^{\circledR}$ or Flavourzyme ${ }^{\circledR}(85)$. Gruyere GI digestion has shown to be an interesting source of Ile-Pro-Ala, and Val-AlaPro-Phe-Pro-Glu-Val, two DPP-IV inhibitory peptides (86). Alaska pollock (Theragra chalcogramma) skin collagen, digested under in vitro $\mathrm{GI}$ conditions, has $\mathrm{IC}_{50}$ values ranging from 1 to $2 \mathrm{mg} \cdot \mathrm{mL}^{-1}$ (87), and similar values have been measured with salmon collagen hydrolyzates obtained with a controlled enzymatic hydrolysis (88). A tetrapeptide Val-Ala-Ala-Ala has been recently isolated from an in vitro GI digest of bovine hemoglobin with an $\mathrm{IC}_{50}$ of $0.141 \pm 0.014 \mathrm{mM}(80)$. A similar trend has been observed with plant protein GI digests. Amaranth (Amaranthus hypochondriacus) seed digests obtained by GI digestion have $\mathrm{IC}_{50}$ values close to $1 \mathrm{mg} \cdot \mathrm{mL}^{-1}$ (89). Cowpea bean GI digestion (Vigna unguiculata), germinated or non-germinated, has produced digests with DPP-IV inhibitory properties at $0.58 \mathrm{mg} \cdot \mathrm{mL}^{-1}$ soluble protein. Two peptides Thr-Thr-Ala-Gly-Leu-Leu-Gln and Lys-Val-Ser-Val-Val-Ala-Leu, characterized by LC-MS-MS in these isolated digests, could have interesting DPP-IV inhibitory properties. A docking study has revealed that these two peptides could strongly interact with the catalytic site of the DPP-IV (90). The process of GI digestion could be able to naturally generate bioactive peptides from dietary proteins with DPP-IV inhibitory properties. The inhibitory potential seems to increase along the progress of digestion: most of the intestinal digests of in vitro GI hemoglobin digestion exhibited lower $\mathrm{IC}_{50}$ values than those of gastric digests (78). However, most of the studies focus on investigating DPP-IV inhibitory properties of protein hydrolyzates during their GI digestion. When digested, protein hydrolyzates often exhibit better DPP-IV inhibitory potentials than those of native proteins. This has been noticed with cuttlefish $(91,92)$, rice, pea, soy, hemp protein (92), or whey protein hydrolyzates (93). A similar observation has been made when comparing the DPP-IV inhibitory potential of cow's milk yogurt from microbial fermentation and its respective GI-derived digests. The DPP-IV inhibitory potential of this yogurt GI digests was significantly better than the yogurt one and was constantly progressing over digestion time (94). GI digestion extends protein degradation and, as a consequence, promotes the release of new potential bioactive peptides. In that sense, most of the studies first focus on optimizing hydrolysis conditions to generate bioactive peptides and then investigate peptide or hydrolyzate stability and their associated bioactivities in simulated GI conditions. Bioactive peptides may be released exogenously (enzymatic hydrolysis and fermentation) or endogenously (GI digestion of dietary or endogenous proteins), but they need to survive GI conditions and to be absorbed, implying crossing the intestinal barrier, to exert their inhibitory potentials on circulating DPP-IV that would impact the most GLP-1 activity. Indeed, GI conditions may compromise their bioavailability and bioactivity. Thus, simulating in vitro GI digestion is a crucial preliminary step to predict the in vivo stability of peptides or protein hydrolyzates in proteolytic conditions. Three peptides were isolated from macroalga hydrolyzates (Palmaria palmata) Ile-leu-Ala-Pro, Leu-Leu-Ala-pro, and Met-Ala-Gly-Val-Asp-His-Ile and proved to keep their DPP-IV inhibitory properties after simulating gastric and intestinal digestion conditions (95). One fraction isolated from an $\alpha$-lactalbumin hydrolyzate was not affected in terms of DPP-IV inhibitory properties after simulating GI digestion $\left(1.20 \pm 0.12 \mathrm{mg} \cdot \mathrm{mL}^{-1}\right)$. Nevertheless, characterizing peptide sequences from various bioactive fractions (digested or not) by LC-MS-MS led to the conclusion that the DPP-IV inhibitory effect observed did not necessarily involve the same sequences before and after simulating GI digestion of the fractions (96). The action of GI enzymes can generate new sequences that might also reveal greater DPP-IV inhibitory properties than the native peptide. This was noticed for three peptides released from a cooked tuna juice hydrolyzate (Thunnus tonggol) obtained by enzymatic hydrolysis. Their DPP-IV inhibitory properties were enhanced after simulating GI digestion (97). Recently, a couple of studies have been investigating the potential bioactivity of endogenous peptides. Endogenous proteins represent a noticeable protein intake, and they are also degraded by GI digestion. Like dietary proteins, they can be regarded as a potential source of bioactive peptides. A human serum albumin hydrolyzate has exhibited 
DPP-IV inhibitory effects that remained in enriched fractions and lysozyme GI digest of the same hydrolyzate (98). Two inhibitory peptides from endogenous proteins, predicted by in silico digestion, have confirmed in vitro their potentials: Met-Ile-Met from human serum albumin $\left(\mathrm{IC}_{50}=800.51 \pm 4.90 \mu \mathrm{M}\right)$ and Arg-ProCys-Phe from endoribonuclease $\left(\mathrm{IC}_{50}=1,056.78 \pm 61.11 \mu \mathrm{M}\right)$. Although their $\mathrm{IC}_{50}$ values do not indicate a strong inhibitory potential compared to Ile-Pro-Ile, endogenous proteins are a complementary source of bioactive peptides (99).

Thus, dietary protein, protein hydrolyzate, or dietary peptide intake could be part of T2DM therapeutic approaches by specifically targeting DPP-IV activity. To date, few in vivo studies have confirmed DPP-IV inhibitory potentials measured in vitro. Studies in streptozotocin-induced obese, Zucker diabetic fatty rat, or lean rats have pointed out that protein hydrolyzate or peptide intake could improve blood glucose, circulating GLP-1 and insulin levels and also decrease plasma DPP-IV activity. This has been described with various hydrolyzates from zein (58), pork gelatin skin (100), salmon gelatin (59), and tilapia gelatin (101). The peptide Leu-Pro-Gln-Asp-Ile-Pro-Pro-Leu, a $\beta$-casein fragment isolated from Gouda cheese, exhibited a high DPP-IV inhibitory potential in vitro $\left(\mathrm{IC}_{50}=46 \mu \mathrm{M}\right)$ and significantly improved blood glucose in diabetic rats after an oral glucose tolerance test. However, the authors did not specify whether this effect was related to DPP-IV activity inhibition (102). Indeed, protein and protein hydrolyzate intake may also improve blood glucose in diabetic rats without reducing plasma DPP-IV activity. In diabetic rats, plasma DPP-IV activity remained higher than in control rats after a protein rich 6-week diet made of either casein or white egg hydrolyzate, although fasting blood glucose and circulating insulin levels were significantly improved (103).

\section{BIOACTIVE PEPTIDES AND OPIOID RECEPTORS: INTESTINAL GLUCONEOGENESIS (IGN) AND PROTEIN-INDUCED SATIETY}

Besides their interaction with gut hormones synthesis and secretion, food-derived peptides could interact with the peripheral opioid receptors and indirectly induce gluconeogenesis that participates in the maintenance of satiety and reduction of food intake. Peripheral opioid receptors are involved in gastric emptying inhibition and food intake-induced satiety by the release of endogenous opioid peptides that act in the CNS (104). Exogenous opioid peptides produced by the GI digestion of alimentary proteins could interact with these receptors and thus intervene in food intake regulation. Casein and soy protein ingestion induces food intake decrease mediated by two distinct signaling pathways, one involving CCK-1R receptors and the other, peripheral $\mu$-opioid receptors (MOR). GI digestion seems to be the source of the release of peptides like $\beta$-casomorphin, derived from caseins and known for its opioid activities $(17,105)$. The name "nutropioids" has been coined for these opioid oligopeptides originating from the diet. Besides, it is known that products of alimentary protein digestion can act as antagonists of MOR present on afferent nerve endings in the intestinal mucosa and portal vein. Detection of these oligopeptides is transmitted to the CNS and induces a decrease in food intake. This regulatory loop comes in complement to the action of the endogenous peptides released following food intake, like endorphins, and demonstrates the plurality of pathways engaged at the peripheral and central levels to promote satiety $(106,107)$. Mithieux et al. described a regulatory loop of food intake implicating portal vein MOR and IGN activated by alimentary protein GI digestion. This theory rests on the anorexigenic properties of glucose: the antagonistic action of oligopeptides in the portal vein MOR activates IGN via a gut-brain axis increasing glycemia that in turn activates hypothalamic regions involved in food intake regulation (108-113). However, only selected dipeptides have been tested so far in these studies to validate the portal vein MOR implication and no food-derived peptide motif has to date, been identified for its anorexigenic properties through this regulatory loop. In contrast, it is noteworthy that the vast majority of proteins investigated as a source of bioactive peptides, of very different animal and plant origins, have been found to produce opioid sequences when hydrolyzed/digested. These food-derived opioid peptides have not been systematically tested for their effect on opioid receptors, but agonistic activity seems to be preponderant, with only few and exclusively from milk products, opioid peptides with antagonist activity. However, it is striking again that all these food-derived opioid peptides have been shown to have a preference for MOR (114). Albeit controversial (115), particularly regarding the importance and relevance of the IGN (high-protein diet context) in comparison to hepatic gluconeogenesis production (116) and species discrepancies (117), this model of protein-induced satiety based on the portal vein MOR and IGN elegantly brings together two critical actors in the regulation of food intake, the opioid system, and glucose homeostasis. It reinforces the central role of the gut-brain axis in energy homeostasis and especially in food intake regulation and highlights the role of the process of digestion in producing food protein-derived bioactive peptides.

\section{CONCLUSION}

For decades, the process of GI digestion has been studied merely for its capacity to transform food into nutriments, the source of energy for our body. It is only recently that the GI tract has been considered a dynamic interface between the luminal environment and the internal environment. Interaction between nutriments and the intestinal barrier elicit the activation of multiple signaling pathways, including some involved in energy homeostasis regulation. With the exponential increase of people affected by diseases linked to the metabolic syndrome, alimentary proteins become the subject of increasing interest since they reduce food intake, induce satiety and increase energy expenditure. Yet, the underlying mechanisms are still not completely elucidated. The in vitro study of some mechanisms, notably the production and secretion of the GI hormones, highlighted the primary role of bioactive peptides originating from protein GI digestion. Regarding the existing links between these peptides and the regulation of intestinal hormones, some signaling pathways have been unveiled implicating a role for the GPCR family of receptors. 
Thus, the presence of these receptors on the apical side of the EECs constitutes the first level of integration of the information on the luminal content. These receptors act as chemodetectors and initiate the translation of the detected information into a hormonal response. Hence, GPCRs attract particular attention as novel targets for obesity and type 2 diabetes treatments. With regards to the peptides, very few structural criteria are known to date to favor these receptors activation.

It is nowadays admitted that the GI tract has the capacity to release bioactive peptides that participate in the regulation of energy homeostasis, from ingested alimentary proteins. While the effects of these peptides confirming a decrease in food intake and an increase in satiety have been demonstrated in vivo, the correlation with an increase in intestinal hormone release or DPP-IV inhibition has not often been established. The presence of the peptides in the intestinal lumen and their potential crossing of the intestinal barrier could be the trigger of other food intake decreasing signaling pathways activation, like the indirect activation of IGN by the portal vein MOR antagonism, or the stimulation of not yet studied intestinal hormones release. Finally, in vivo

\section{REFERENCES}

1. Cummings DE, Overduin J. Gastrointestinal regulation of food intake. J Clin Invest (2007) 117(1):13-23. doi:10.1172/JCI30227

2. Sternini C, Anselmi L, Rozengurt E. Enteroendocrine cells: a site of 'taste' in gastrointestinal chemosensing. Curr Opin Endocrinol Diabetes Obes (2008) 15(1):73-8. doi:10.1097/MED.0b013e3282f43a73

3. Morton GJ, Cummings DE, Baskin DG, Barsh GS, Schwartz MW. Central nervous system control of food intake and body weight. Nature (2006) 443(7109):289-95. doi:10.1038/nature05026

4. Wren AM, Bloom SR. Gut hormones and appetite control. Gastroenterology (2007) 132(6):2116-30. doi:10.1053/j.gastro.2007.03.048

5. Moran TH, Dailey MJ. Gut peptides: targets for antiobesity drug development? Endocrinology (2009) 150(6):2526-30. doi:10.1210/en.2009-0003

6. Westerterp-Plantenga MS, Lemmens SG, Westerterp KR. Dietary protein its role in satiety, energetics, weight loss and health. Br J Nutr (2012) 108(S2): S105-12. doi:10.1017/S0007114512002589

7. Bensaid A, Tome D, Gietzen D, Even P, Morens C, Gausseres N, et al. Protein is more potent than carbohydrate for reducing appetite in rats. Physiol Behav (2002) 75(4):577-82. doi:10.1016/S0031-9384(02)00646-7

8. Hall WL, Millward DJ, Long SJ, Morgan LM. Casein and whey exert different effects on plasma amino acid profiles, gastrointestinal hormone secretion and appetite. Br J Nutr (2003) 89(2):239-48. doi:10.1079/BJN2002760

9. Westerterp-Plantenga MS. Protein intake and energy balance. Regul Pept (2008) 149(1-3):67-9. doi:10.1016/j.regpep.2007.08.026

10. Layman DK, Boileau RA, Erickson DJ, Painter JE, Shiue H, Sather C, et al. A reduced ratio of dietary carbohydrate to protein improves body composition and blood lipid profiles during weight loss in adult women. J Nutr (2003) 133(2):411-7.

11. Horner K, Drummond E, Brennan L. Bioavailability of milk protein-derived bioactive peptides: a glycaemic management perspective. Nutr Res Rev (2016) 29(1):91-101. doi:10.1017/S0954422416000032

12. Shi G, Leray V, Scarpignato C, Bentouimou N, Varannes S, Cherbut C, et al. Specific adaptation of gastric emptying to diets with differing protein content in the rat: is endogenous cholecystokinin implicated? Gut (1997) 41(5):612-8. doi:10.1136/gut.41.5.612

13. Nishi T, Hara H, Tomita F. Soybean $\beta$-conglycinin peptone suppresses food intake and gastric emptying by increasing plasma cholecystokinin levels in rats. J Nutr (2003) 133(2):352-7.

14. Liddle RA, Green GM, Conrad CK, Williams JA. Proteins but not amino acids, carbohydrates, or fats stimulate cholecystokinin secretion in the rat. Am J Physiol (1986) 251(2 Pt 1):G243-8. identification of the peptides produced during GI digestion and responsible for the described effects is still difficult to realize. Therefore, analytical strategies have been implemented in vitro in order to follow the release of peptides during GI digestion and meanwhile to reveal their bioactive potential.

\section{AUTHOR CONTRIBUTIONS}

JC and DD participated in all steps of preparation of this manuscript and contributed equally to this work. RR and PD participated in the editing of the manuscript and revised it critically. BC was awarded the funding and participated in the conception and in the editing of the manuscript and revised it critically.

\section{FUNDING}

This work was supported by the CPER "Alibiotech" funding and a grant of the Nord Pas de Calais Region: "2nd appel à projet, Programme projets émergents."

15. Brennan IM, Luscombe-Marsh ND, Seimon RV, Otto B, Horowitz M, Wishart $\mathrm{JM}$, et al. Effects of fat, protein, and carbohydrate and protein load on appetite, plasma cholecystokinin, peptide YY, and ghrelin, and energy intake in lean and obese men. Am J Physiol Gastrointest Liver Physiol (2012) 303(1):G129-40. doi:10.1152/ajpgi.00478.2011

16. Sharara A, Bouras EP, Misukonis M, Liddle RA. Evidence for indirect dietary regulation of cholecystokinin release in rats. Am J Physiol (1993) 265(1):G107-12.

17. Pupovac J, Anderson GH. Dietary peptides induce satiety via cholecystokinin-A and peripheral opioid receptors in rats. J Nutr (2002) 132(9):2775-80.

18. Nishi T, Hara H, Hira T, Tomita F. Dietary protein peptic hydrolysates stimulate cholecystokinin release via direct sensing by rat intestinal mucosal cells. Exp Biol Med (2001) 226(11):1031-6. doi:10.1177/153537020122601110

19. Cudennec B, Ravallec-Plé R, Courois E, Fouchereau-Peron M. Peptides from fish and crustacean by-products hydrolysates stimulate cholecystokinin release in STC-1 cells. Food Chem (2008) 111(4):970-5. doi:10.1016/j. foodchem.2008.05.016

20. Cudennec B, Fouchereau-Peron M, Ferry F, Duclos E, Ravallec R. In vitro and in vivo evidence for a satiating effect of fish protein hydrolysate obtained from blue whiting (Micromesistius poutassou) muscle. J Funct Foods (2012) 4(1):271-7. doi:10.1016/j.jff.2011.12.003

21. Cordier-Bussat M, Bernard C, Haouche S, Roche C, Abello J, Chayvialle JA, et al. Peptones stimulate cholecystokinin secretion and gene transcription in the intestinal cell line STC-1. Endocrinology (1997) 138(3):1137-44. doi:10.1210/endo.138.3.5023

22. Geraedts MC, Troost FJ, Fischer MA, Edens L, Saris WH. Direct induction of CCK and GLP-1 release from murine endocrine cells by intact dietary proteins. Mol Nutr Food Res (2011) 55(3):476-84. doi:10.1002/mnfr.201000142

23. Nishi $T$, Hara $H$, Asano $K$, Tomita $F$. The soybean $\beta$-conglycinin $\beta$ 51-63 fragment suppresses appetite by stimulating cholecystokinin release in rats. J Nutr (2003) 133(8):2537-42.

24. Sufian MK, Hira T, Miyashita K, Nishi T, Asano K, Hara H. Pork peptone stimulates cholecystokinin secretion from enteroendocrine cells and suppresses appetite in rats. Biosci Biotechnol Biochem (2006) 70(8):1869-74. doi:10.1271/ bbb.60046

25. Wang Y, Prpic V, Green GM, Reeve JR Jr, Liddle RA. Luminal CCK-releasing factor stimulates CCK release from human intestinal endocrine and STC-1 cells. Am J Physiol Gastrointest Liver Physiol (2002) 282(1):G16-22.

26. Spannagel AW, Green GM, Guan D, Liddle RA, Faull K, Reeve JR. Purification and characterization of a luminal cholecystokinin-releasing factor from rat intestinal secretion. Proc Natl Acad Sci U S A (1996) 93(9):4415-20. doi:10.1073/pnas.93.9.4415 
27. Tarasova N, Spannagel AW, Green GM, Gomez G, Reed JT, Thompson JC, et al. Distribution and localization of a novel cholecystokinin-releasing factor in the rat gastrointestinal tract 1. Endocrinology (1997) 138(12):5550-4. doi:10.1210/endo.138.12.5554

28. Miyasaka K, Guan D, Liddle RA, Green GM. Feedback regulation by trypsin: evidence for intraluminal CCK-releasing peptide. Am J Physiol (1989) 257(2):G175-81.

29. Spannagel AW, Reeve JR Jr, Greeley GH Jr, Yanaihara N, Liddle RA, Green GM. Bioactivity of intraduodenally and intravenously infused fragments of luminal cholecystokinin releasing factor (LCRF). Regul Pept (1998) 73(3):161-4. doi:10.1016/S0167-0115(97)01074-4

30. Némoz-Gaillard E, Bernard C, Abello J, Cordier-Bussat M, Chayvialle JA, Cuber JC. Regulation of cholecystokinin secretion by peptones and peptidomimetic antibiotics in STC-1 cells. Endocrinology (1998) 139(3):932-8. doi:10.1210/en.139.3.932

31. Yoshida H, Tsunoda Y, Owyang C. Diazepam-binding inhibitor33-50 elicits Ca2+ oscillation and CCK secretion in STC-1 cells via L-type Ca2+ channels. Am J Physiol Gastrointest Liver Physiol (1999) 276(3):G694-702.

32. Choi S, Lee M, Shiu AL, Yo SJ, Aponte GW. Identification of a protein hydrolysate responsive $\mathrm{G}$ protein-coupled receptor in enterocytes. Am J Physiol Gastrointest Liver Physiol (2007) 292(1):G98-112. doi:10.1152/ajpgi. 00295.2006

33. Choi S, Lee M, Shiu AL, Yo SJ, Hallden G, Aponte GW. GPR93 activation by protein hydrolysate induces CCK transcription and secretion in STC-1 cells. Am J Physiol Gastrointest Liver Physiol (2007) 292(5):G1366-75. doi:10.1152/ ajpgi.00516.2006

34. Conigrave AD, Hampson DR. Broad-spectrum amino acid-sensing class $C$ G-protein coupled receptors: molecular mechanisms, physiological significance and options for drug development. Pharmacol Ther (2010) 127(3):252-60. doi:10.1016/j.pharmthera.2010.04.007

35. Conigrave A, Mun H-C, Brennan SC. Physiological significance of L-amino acid sensing by extracellular Ca2+-sensing receptors. Biochem Soc Trans (2007) 35(5):1195-8. doi:10.1042/BST0351195

36. Mangel AW, Prpic V, Wong H, Basavappa S, Hurst LJ, Scott L, et al. Phenylalanine-stimulated secretion of cholecystokinin is calcium dependent. Am J Physiol (1995) 268(1 Pt 1):G90-4.

37. Hira T, Nakajima S, Eto Y, Hara H. Calcium-sensing receptor mediates phenylalanine-induced cholecystokinin secretion in enteroendocrine STC-1 cells. FEBS J (2008) 275(18):4620-6. doi:10.1111/j.1742-4658.2008.06604.x

38. Nakajima S, Hira T, Eto Y, Asano K, Hara H. Soybean $\beta 51-63$ peptide stimulates cholecystokinin secretion via a calcium-sensing receptor in enteroendocrine STC-1 cells. Regul Pept (2010) 159(1-3):148-55. doi:10.1016/j.regpep. 2009.11.007

39. Nakajima S, Hira T, Hara H. Calcium-sensing receptor mediates dietary peptide-induced CCK secretion in enteroendocrine STC-1 cells. Mol Nutr Food Res (2012) 56(5):753-60. doi:10.1002/mnfr.201100666

40. Gevrey JC, Cordier-Bussat M, Nemoz-Gaillard E, Chayvialle JA, Abello J. Co-requirement of cyclic AMP- and calcium-dependent protein kinases for transcriptional activation of cholecystokinin gene by protein hydrolysates. J Biol Chem (2002) 277(25):22407-13. doi:10.1074/jbc.M201624200

41. Saxena M, Williams S, Taskén K, Mustelin T. Crosstalk between cAMPdependent kinase and MAP kinase through a protein tyrosine phosphatase. Nat Cell Biol (1999) 1(5):305-10. doi:10.1038/13024

42. Zanassi P, Paolillo M, Feliciello A, Avvedimento EV, Gallo V, Schinelli S. cAMPdependent protein kinase induces cAMP-response element-binding protein phosphorylation via an intracellular calcium release/ERK-dependent pathway in striatal neurons. J Biol Chem (2001) 276(15):11487-95. doi:10.1074/jbc. M007631200

43. Alleaume $\mathrm{C}$, Eychène A, Caigneaux E, Muller J-M, Philippe M. Vasoactive intestinal peptide stimulates proliferation in HT29 human colonic adenocarcinoma cells: concomitant activation of Ras/Rap1-B-Raf-ERK signalling pathway. Neuropeptides (2003) 37(2):98-104. doi:10.1016/S0143-4179(03)00020-9

44. Reidelberger RD, Heimann D, Kelsey L, Hulce M. Effects of peripheral CCK receptor blockade on feeding responses to duodenal nutrient infusions in rats. Am J Physiol Regul Integr Comp Physiol (2003) 284(2):R389-98. doi:10.1152/ ajpregu.00529.2002

45. Raybould HE, Zittel TT, Holzer HH, Lloyd KK, Meyer JH. Gastroduodenal sensory mechanisms and CCK in inhibition of gastric emptying in response to a meal. Dig Dis Sci (1994) 39(12):41S-3S. doi:10.1007/BF02300368
46. Darcel NP, Liou AP, Tome D, Raybould HE. Activation of vagal afferents in the rat duodenum by protein digests requires PepT1. J Nutr (2005) 135(6):1491-5.

47. Liou AP, Chavez DI, Espero E, Hao S, Wank SA, Raybould HE. Protein hydrolysate-induced cholecystokinin secretion from enteroendocrine cells is indirectly mediated by the intestinal oligopeptide transporter PepT1. Am J Physiol Gastrointest Liver Physiol (2011) 300(5):G895-902. doi:10.1152/ ajpgi.00521.2010

48. Matsumura K, Miki T, Jhomori T, Gonoi T, Seino S. Possible role of PEPT1 in gastrointestinal hormone secretion. Biochem Biophys Res Commun (2005) 336(4):1028-32. doi:10.1016/j.bbrc.2005.08.259

49. Staljanssens D, Van Camp J, Billiet A, De Meyer T, Al Shukor N, De Vos WH, et al. Screening of soy and milk protein hydrolysates for their ability to activate the CCK1 receptor. Peptides (2012) 34(1):226-31. doi:10.1016/j.peptides. 2011.11.019

50. Foltz M, Ansems P, Schwarz J, Tasker MC, Lourbakos A, Gerhardt CC. Protein hydrolysates induce CCK release from enteroendocrine cells and act as partial agonists of the CCK1 receptor. J Agric Food Chem (2008) 56(3):837-43. doi:10.1021/jf072611h

51. Ripken D, Van der Wielen N, Van der Meulen J, Schuurman T, Witkamp R, Hendriks $\mathrm{H}$, et al. Cholecystokinin regulates satiation independently of the abdominal vagal nerve in a pig model of total subdiaphragmatic vagotomy. Physiol Behav (2015) 139:167-76. doi:10.1016/j.physbeh.2014.11.031

52. Meek CL, Lewis HB, Reimann F, Gribble FM, Park AJ. The effect of bariatric surgery on gastrointestinal and pancreatic peptide hormones. Peptides (2016) 77:28-37. doi:10.1016/j.peptides.2015.08.013

53. Hutchison AT, Feinle-Bisset C, Fitzgerald PC, Standfield S, Horowitz M, Clifton PM, et al. Comparative effects of intraduodenal whey protein hydrolysate on antropyloroduodenal motility, gut hormones, glycemia, appetite, and energy intake in lean and obese men. Am J Clin Nutr (2015) 102(6):1323-31. doi:10.3945/ajcn.115.114538

54. Stringer DM, Taylor CG, Appah P, Blewett H, Zahradka P. Consumption of buckwheat modulates the post-prandial response of selected gastrointestinal satiety hormones in individuals with type 2 diabetes mellitus. Metabolism (2013) 62(7):1021-31. doi:10.1016/j.metabol.2013.01.021

55. Ma J, Stevens JE, Cukier K, Maddox AF, Wishart JM, Jones KL, et al. Effects of a protein preload on gastric emptying, glycemia, and gut hormones after a carbohydrate meal in diet-controlled type 2 diabetes. Diabetes Care (2009) 32(9):1600-2. doi:10.2337/dc09-0723

56. Lejeune MP, Westerterp KR, Adam TC, Luscombe-Marsh ND, WesterterpPlantenga MS. Ghrelin and glucagon-like peptide 1 concentrations, 24-h satiety, and energy and substrate metabolism during a high-protein diet and measured in a respiration chamber. Am J Clin Nutr (2006) 83(1):89-94.

57. Diepvens K, Häberer D, Westerterp-Plantenga M. Different proteins and biopeptides differently affect satiety and anorexigenic/orexigenic hormones in healthy humans. Int J Obes (2008) 32(3):510-8. doi:10.1038/sj.ijo.0803758

58. Mochida T, Hira T, Hara H. The corn protein, zein hydrolysate, administered into the ileum attenuates hyperglycemia via its dual action on glucagon-like peptide- 1 secretion and dipeptidyl peptidase-IV activity in rats. Endocrinology (2010) 151(7):3095-104. doi:10.1210/en.2009-1510

59. Hsieh C-H, Wang T-Y, Hung C-C, Chen M, Hsu K. Improvement of glycemic control in streptozotocin-induced diabetic rats by Atlantic salmon skin gelatin hydrolysate as the dipeptidyl-peptidase IV inhibitor. Food Funct (2015) 6(6):1887-92. doi:10.1039/c5fo00124b

60. Ishikawa Y, Hira T, Inoue D, Harada Y, Hashimoto H, Fujii M, et al. Rice protein hydrolysates stimulate GLP-1 secretion, reduce GLP-1 degradation, and lower the glycemic response in rats. Food Funct (2015) 6(8):2525-34. doi:10.1039/c4fo01054j

61. Power-Grant O, Bruen C, Brennan L, Giblin L, Jakeman P, FitzGerald R. In vitro bioactive properties of intact and enzymatically hydrolysed whey protein: targeting the enteroinsular axis. Food Funct (2015) 6(3):972-80. doi:10.1039/c4fo00983e

62. Elliott RM, Morgan LM, Tredger JA, Deacon S, Wright J, Marks V. Glucagonlike peptide-1(7-36)amide and glucose-dependent insulinotropic polypeptide secretion in response to nutrient ingestion in man: acute post-prandial and 24-h secretion patterns. J Endocrinol (1993) 138(1):159-66. doi:10.1677/ joe. 0.1380159

63. Klaauw AA, Keogh JM, Henning E, Trowse VM, Dhillo WS, Ghatei MA, et al. High protein intake stimulates postprandial GLP1 and PYY release. Obesity (2013) 21(8):1602-7. doi:10.1002/oby.20154 
64. Dougkas A, Östman E. Protein-enriched liquid preloads varying in macronutrient content modulate appetite and appetite-regulating hormones in healthy adults. J Nutr (2016) 146(3):637-45. doi:10.3945/jn.115.217224

65. Herrmann C, Göke R, Richter G, Fehmann H-C, Arnold R, Göke B. Glucagonlike peptide-1 and glucose-dependent insulin-releasing polypeptide plasma levels in response to nutrients. Digestion (1995) 56(2):117-26. doi:10.1159/ 000201231

66. Hira T, Mochida T, Miyashita K, Hara H. GLP-1 secretion is enhanced directly in the ileum but indirectly in the duodenum by a newly identified potent stimulator, zein hydrolysate, in rats. Am J Physiol Gastrointest Liver Physiol (2009) 297(4):G663-71. doi:10.1152/ajpgi.90635.2008

67. Cordier-Bussat M, Bernard C, Levenez F, Klages N, Laser-Ritz B, Philippe J, et al. Peptones stimulate both the secretion of the incretin hormone glucagonlike peptide 1 and the transcription of the proglucagon gene. Diabetes (1998) 47(7):1038-45. doi:10.2337/diabetes.47.7.1038

68. Reimer RA, Darimont C, Gremlich S, Nicolas-Metral V, Ruegg UT, Mace K. A human cellular model for studying the regulation of glucagon-like peptide-1 secretion. Endocrinology (2001) 142(10):4522-8. doi:10.1210/endo.142.10.8415

69. Reimann F, Williams L, da Silva Xavier G, Rutter G, Gribble F. Glutamine potently stimulates glucagon-like peptide-1 secretion from GLUTag cells. Diabetologia (2004) 47(9):1592-601. doi:10.1007/s00125-004-1498-0

70. Tolhurst G, Zheng Y, Parker HE, Habib AM, Reimann F, Gribble FM. Glutamine triggers and potentiates glucagon-like peptide- 1 secretion by raising cytosolic Ca2+ and cAMP. Endocrinology (2011) 152(2):405-13. doi:10.1210/ en.2010-0956

71. Meek CL, Lewis HB, Vergese B, Park A, Reimann F, Gribble F. The effect of encapsulated glutamine on gut peptide secretion in human volunteers. Peptides (2016) 77:38-46. doi:10.1016/j.peptides.2015.10.008

72. Mace OJ, Schindler M, Patel S. The regulation of K- and L-cell activity by GLUT2 and the calcium-sensing receptor CasR in rat small intestine. J Physiol (2012) 590(12):2917-36. doi:10.1113/jphysiol.2011.223800

73. Oya M, Kitaguchi T, Pais R, Reimann F, Gribble F, Tsuboi T. The G proteincoupled receptor family C group 6 subtype A (GPRC6A) receptor is involved in amino acid-induced glucagon-like peptide-1 secretion from GLUTag cells. J Biol Chem (2013) 288(7):4513-21. doi:10.1074/jbc.M112.402677

74. Le Nevé B, Daniel H. Selected tetrapeptides lead to a GLP-1 release from the human enteroendocrine cell line NCI-H716. Regul Pept (2011) 167(1):14-20. doi:10.1016/j.regpep.2010.10.010

75. Diakogiannaki E, Pais R, Tolhurst G, Parker HE, Horscroft J, Rauscher B, et al. Oligopeptides stimulate glucagon-like peptide-1 secretion in mice through proton-coupled uptake and the calcium-sensing receptor. Diabetologia (2013) 56(12):2688-96. doi:10.1007/s00125-013-3037-3

76. Pais R, Gribble FM, Reimann F. Signalling pathways involved in the detection of peptones by murine small intestinal enteroendocrine L-cells. Peptides (2016) 77:9-15. doi:10.1016/j.peptides.2015.07.019

77. Reimer RA. Meat hydrolysate and essential amino acid-induced glucagon-like peptide-1 secretion, in the human NCI-H716 enteroendocrine cell line, is regulated by extracellular signal-regulated kinase $1 / 2$ and p38 mitogen-activated protein kinases. J Endocrinol (2006) 191(1):159-70. doi:10.1677/joe.1.06557

78. Caron J, Domenger D, Belguesmia Y, Kouach M, Lesage J, Goossens J-F, et al. Protein digestion and energy homeostasis: how generated peptides may impact intestinal hormones? Food Res Intern (2016) 88(Pt B):310-8. doi:10.1016/j.foodres.2015.12.018

79. Gevrey JC, Malapel M, Philippe J, Mithieux G, Chayvialle JA, Abello J, et al. Protein hydrolysates stimulate proglucagon gene transcription in intestinal endocrine cells via two elements related to cyclic AMP response element. Diabetologia (2004) 47(5):926-36. doi:10.1007/s00125-004-1380-0

80. Caron J, Cudennec B, Domenger D, Belguesmia Y, Flahaut C, Kouach M, et al. Simulated GI digestion of dietary protein: release of new bioactive peptides involved in gut hormone secretion. Food Res Intern (2016) 89:382-90. doi:10.1016/j.foodres.2016.08.033

81. Jao C-L, Hung C-C, Tung Y-S, Lin P-Y, Chen M-C, Hsu K-C. The development of bioactive peptides from dietary proteins as a dipeptidyl peptidase IV inhibitor for the management of type 2 diabetes. Biomedicine (2015) 5(3):1-7. doi:10.7603/s40681-015-0014-9

82. Drucker DJ, Nauck MA. The incretin system: glucagon-like peptide-1 receptor agonists and dipeptidyl peptidase- 4 inhibitors in type 2 diabetes. Lancet (2006) 368(9548):1696-705. doi:10.1016/S0140-6736(06)69705-5
83. Mulvihill EE, Drucker DJ. Pharmacology, physiology, and mechanisms of action of dipeptidyl peptidase-4 inhibitors. Endocr Rev (2014) 35(6): 992-1019. doi:10.1210/er.2014-1035

84. Godinho R, Mega C, Teixeira-de-Lemos E, Carvalho E, Teixeira F, Fernandes R, et al. The place of dipeptidyl peptidase- 4 inhibitors in type 2 diabetes therapeutics: a "me too" or "the special one" Antidiabetic class? J Diabetes Res (2015) 2015:28. doi:10.1155/2015/806979

85. Lacroix IME, Li-Chan ECY. Dipeptidyl peptidase-IV inhibitory activity of dairy protein hydrolysates. Int Dairy J (2012) 25(2):97-102. doi:10.1016/j. idairyj.2012.01.003

86. Kopf-Bolanz KA, Schwander F, Gijs M, Vergères G, Portmann R, Egger L. Impact of milk processing on the generation of peptides during digestion. Int Dairy J (2014) 35(2):130-8. doi:10.1016/j.idairyj.2013.10.012

87. Guo L, Harnedy PA, Zhang L, Li B, Zhang Z, Hou H, et al. In vitro assessment of the multifunctional bioactive potential of Alaska pollock skin collagen following simulated gastrointestinal digestion. J Sci Food Agric (2015) 95(7): 1514-20. doi:10.1002/jsfa.6854

88. Li-Chan EC, Hunag S-L, Jao C-L, Ho K-P, Hsu K-C. Peptides derived from Atlantic salmon skin gelatin as dipeptidyl-peptidase IV inhibitors. J Agric Food Chem (2012) 60(4):973-8. doi:10.1021/jf204720q

89. Velarde-Salcedo AJ, Barrera-Pacheco A, Lara-González S, Montero-Morán GM, Díaz-Gois A, de Mejia EG, et al. In vitro inhibition of dipeptidyl peptidase IV by peptides derived from the hydrolysis of amaranth (Amaranthus hypochondriacus L.) proteins. Food Chem (2013) 136(2):758-64. doi:10.1016/j. foodchem.2012.08.032

90. De Souza Rocha T, Hernandez LMR, Chang YK, de Mejía EG. Impact of germination and enzymatic hydrolysis of cowpea bean (Vigna unguiculata) on the generation of peptides capable of inhibiting dipeptidyl peptidase IV. Food Res Intern (2014) 64:799-809. doi:10.1016/j.foodres.2014.08.016

91. Cudennec B, Balti R, Ravallec R, Caron J, Bougatef A, Dhulster P, et al. In vitro evidence for gut hormone stimulation release and dipeptidylpeptidase IV inhibitory activity of protein hydrolysate obtained from cuttlefish (Sepia officinalis) viscera. Food Res Intern (2015) 78:238-45. doi:10.1016/ j.foodres.2015.10.003

92. Nongonierma A, FitzGerald R. Investigation of the potential of hemp, pea, rice and soy protein hydrolysates as a source of dipeptidyl peptidase IV (DPP-IV) inhibitory peptides. Food Dig Res Curr Opin (2015) 6:19-29. doi:10.1007/s13228-015-0039-2

93. Nongonierma AB, FitzGerald RJ. Dipeptidyl peptidase IV inhibitory properties of a whey protein hydrolysate: influence of fractionation, stability to simulated gastrointestinal digestion and food-drug interaction. Int Dairy J (2013) 32(1):33-9. doi:10.1016/j.idairyj.2013.03.005

94. Jin Y, Yu Y, Qi Y, Wang F, Yan J, Zou H. Peptide profiling and the bioactivity character of yogurt in the simulated gastrointestinal digestion. J Proteomics (2016) 141:24-46. doi:10.1016/j.jprot.2016.04.010

95. Harnedy PA, O’Keeffe MB, FitzGerald RJ. Purification and identification of dipeptidyl peptidase (DPP) IV inhibitory peptides from the macroalga Palmaria palmata. Food Chem (2015) 172(0):400-6. doi:10.1016/j.foodchem. 2014.09.083

96. Nongonierma AB, FitzGerald RJ. Prospects for the management of type 2 diabetes using food protein-derived peptides with dipeptidyl peptidase IV (DPP-IV) inhibitory activity. Curr Opin Food Sci (2016) 8:19-24. doi:10.1016/ j.cofs.2016.01.007

97. Huang S-L, Jao C-L, Ho K-P, Hsu K-C. Dipeptidyl-peptidase IV inhibitory activity of peptides derived from tuna cooking juice hydrolysates. Peptides (2012) 35(1):114-21. doi:10.1016/j.peptides.2012.03.006

98. Dave LA, Hayes M, Mora L, Montoya CA, Moughan PJ, Rutherfurd SM. Gastrointestinal endogenous protein-derived bioactive peptides: an in vitro study of their gut modulatory potential. Int J Mol Sci (2016) 17(4):482. doi:10.3390/ijms17040482

99. Dave LA, Hayes M, Moughan PJ, Rutherfurd SM. Novel dipeptidyl peptidase IV inhibitory and antioxidant peptides derived from human gastrointestinal endogenous proteins. Int J Pept Res Ther (2016) 22(3):355-69. doi:10.1007/ s10989-016-9515-y

100. Huang S-L, Hung C-C, Jao C-L, Tung Y-S, Hsu K-C. Porcine skin gelatin hydrolysate as a dipeptidyl peptidase IV inhibitor improves glycemic control in streptozotocin-induced diabetic rats. J Funct Foods (2014) 11(0):235-42. doi:10.1016/j.jff.2014.09.010 
101. Wang Y, Landheer S, van Gilst WH, van Amerongen A, Hammes H-P, Henning RH, et al. Attenuation of renovascular damage in Zucker diabetic fatty rat by NWT-03, an egg protein hydrolysate with ACE-and DPP4inhibitory Activity. PLoS One (2012) 7(10):e46781. doi:10.1371/journal. pone. 0046781

102. Uenishi H, Kabuki T, Seto Y, Serizawa A, Nakajima H. Isolation and identification of casein-derived dipeptidyl-peptidase 4 (DPP-4)-inhibitory peptide LPQNIPPL from gouda-type cheese and its effect on plasma glucose in rats. Int Dairy J (2012) 22(1):24-30. doi:10.1016/j.idairyj.2011.08.002

103. Ochiai M, Kuroda T, Matsuo T. Increased muscular triglyceride content and hyperglycemia in Goto-Kakizaki rat are decreased by egg white hydrolysate. Int J Food Sci Nutr (2014) 65(4):495-501. doi:10.3109/09637486. 2013.879288

104. Janssen P, Pottel H, Vos R, Tack J. Endogenously released opioids mediate meal-induced gastric relaxation via peripheral mu-opioid receptors. Aliment Pharmacol Ther (2011) 33(5):607-14. doi:10.1111/j.1365-2036. 2010.04557.x

105. Froetschel M, Azain M, Edwards G, Barb C, Amos H. Opioid and cholecystokinin antagonists alleviate gastric inhibition of food intake by premeal loads of casein in meal-fed rats. J Nutr (2001) 131(12):3270-6.

106. Duraffourd C, De Vadder F, Goncalves D, Delaere F, Penhoat A, Brusset B, et al. $\mathrm{Mu}$-opioid receptors and dietary protein stimulate a gut-brain neural circuitry limiting food intake. Cell (2012) 150(2):377-88. doi:10.1016/j.cell. 2012.05.039

107. Pfluger PT, Schriever SC, Tschöp MH. Nutropioids, hedonism in the gut? Cell Metab (2012) 16(2):137-9. doi:10.1016/j.cmet.2012.07.011

108. Mithieux G, Misery P, Magnan C, Pillot B, Gautier-Stein A, Bernard C, et al. Portal sensing of intestinal gluconeogenesis is a mechanistic link in the diminution of food intake induced by diet protein. Cell Metab (2005) 2(5):321-9. doi:10.1016/j.cmet.2005.09.010

109. De Vadder F, Gautier-Stein A, Mithieux G. [Opioid receptors associated with portal vein regulate a gut-brain neural circuitry limiting food intake]. Med Sci (Paris) (2013) 29(1):31-3. doi:10.1051/medsci/2013291010
110. De Vadder F, Gautier-Stein A, Mithieux G. Satiety and the role of $\mu$-opioid receptors in the portal vein. Curr Opin Pharmacol (2013) 13(6):959-63. doi:10.1016/j.coph.2013.09.003

111. Mithieux G. Crosstalk between gastrointestinal neurons and the brain in the control of food intake. Best Pract Res Clin Endocrinol Metab (2014) 28(5):739-44. doi:10.1016/j.beem.2014.03.004

112. Mithieux G. Nutropioids regulate gut-brain circuitry controlling food intake. In: Delhanty PJD, van der Lely AJ, editors. How Gut and Brain Control Metabolism. Karger Publishers (2014). p. 155-62.

113. Mithieux G. Metabolic effects of portal vein sensing. Diabetes Obes Metab (2014) 16(S1):56-60. doi:10.1111/dom.12338

114. Teschemacher H. Opioid receptor ligands derived from food proteins. Curr Pharm Des (2003) 9(16):1331-44. doi:10.2174/1381612033454856

115. Westerterp-Plantenga $M$, Luscombe-Marsh N, Lejeune $M$, Diepvens K, Nieuwenhuizen A, Engelen M, et al. Dietary protein, metabolism, and body-weight regulation: dose-response effects. Int J Obes (2006) 30:S16-23. doi:10.1038/sj.ijo.0803487

116. Watford M. Is the small intestine a gluconeogenic organ? Nutr Rev (2005) 63(10):356-60. doi:10.1111/j.1753-4887.2005.tb00114.x

117. L'Heureux-Bouron D, Tomé D, Rampin O, Even PC, Larue-Achagiotis C, Fromentin $\mathrm{G}$. Total subdiaphragmatic vagotomy does not suppress high protein diet-induced food intake depression in rats. J Nutr (2003) 133(8):2639-42.

Conflict of Interest Statement: The authors declare that the research was conducted in the absence of any commercial or financial relationships that could be construed as a potential conflict of interest.

Copyright (c) 2017 Caron, Domenger, Dhulster, Ravallec and Cudennec. This is an open-access article distributed under the terms of the Creative Commons Attribution License (CC BY). The use, distribution or reproduction in other forums is permitted, provided the original author(s) or licensor are credited and that the original publication in this journal is cited, in accordance with accepted academic practice. No use, distribution or reproduction is permitted which does not comply with these terms. 